\title{
COMPUTATIONAL AERODYNAMIC ANALYSIS OF BLENDED WING BODY MAV DESIGN
}

\author{
Md. Akhtar khan ${ }^{1}$, Arjun Jagini ${ }^{2}$ \\ ${ }^{1}$ Assistant Professor, Department of Aerospace Engineering, GITAM University, Hyderabad \\ ${ }^{2}$ Analyst, emug technologies Limited, Hyderabad
}

\begin{abstract}
The Blended Wing Body $(B W B)$ configuration has the potential to change the way subsonic transport airplanes are designed. In the past ten years, fuel efficiency and noise reduction have become the two biggest challenges for aircraft manufacturers. This paper deals with the computational aerodynamic analysis of a BWB airplane at subsonic speeds using Ansys CFD as a simulation tool and ICEM CFD as a modeling tool. The study will focus on the aerodynamic characteristics such as the pressure, velocity variation over the body at different angle of attack. We are also calculating the aerodynamic efficiency (lift force to drag force ratio) so that we can compare the performance of a BWB aircraft with a conventional aircraft.
\end{abstract}

Keywords: Blended Wing Body (BWB), Hybrid Wing, Tetra Mesh, Square Cube Law, ICEM CFD

\section{INTRODUCTION}

The current design of transport aircraft has not changed significantly in the past few decades; rather incremental design optimization has taken place on each new generation of aircraft. Growing environmental concerns and fuel prices are the driving factors behind the need for more fuel efficient means of air travel $[1,8]$. With the ever increasing global carbon emissions crisis, coupled with the financial aspect of rising fuel costs, the efficiency of modern aircraft is now more important than ever. Therefore the BWB configuration designates an alternative aircraft configuration where the wing and fuselage are integrated which results essentially in a hybrid flying wing shape. BWB is a hybrid of flying wing aircraft and the conventional Aircraft where the body is designed to have a shape of an airfoil and carefully streamlined with the wing to have a desired plan form.[2]

Growing environmental concerns and fuel prices are the driving factors behind the need for more fuel efficient means of air travel. With the ever increasing global carbon emissions crisis, coupled with the financial aspect of rising fuel costs, the efficiency of modern aircraft is now more important than ever. Airline operators are under increasing pressure from the government and the general public to operate more efficient, less polluting aircraft. The BlendedWing-Body (BWB) configuration has the potential to change the way we approach large transport aircraft design as shown in Fig.1.[3,5]

The main aerodynamic advantages of the BWB over conventional aircraft are its lower area-to-volume ratio, lower induced and parasitic drag. Because of these reasons, the lift-to-drag ratio can increase considerably. Another important advantage is the increased useful passenger space. By far the greatest of these advantages is the relatively large increase in payload per unit span. However, the BWB design also introduces a number of challenges such as the vastly increased sensitivity to center of gravity position, static stability issues and the manufacturing difficulty.

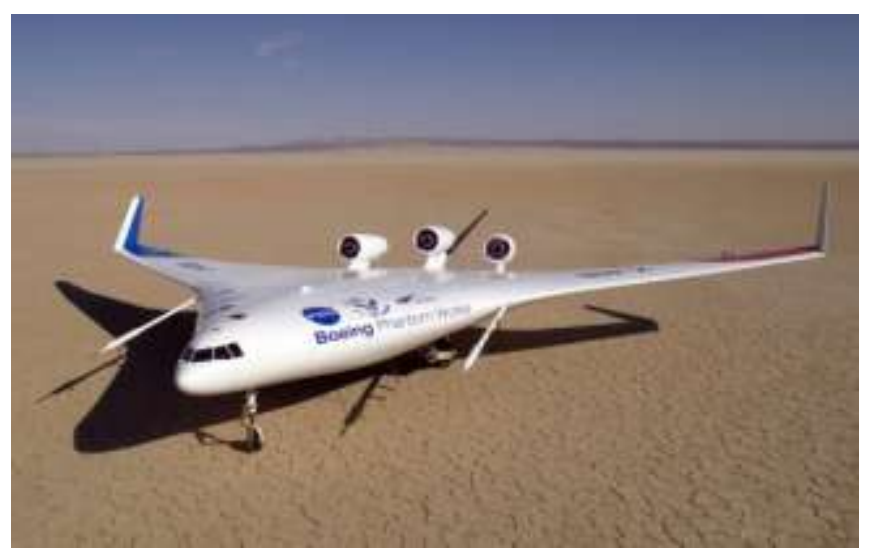

Fig.1. Boeing X-48C BWB Design[3]

\subsection{The Square Cube Law}

One of the reasons physics favors large BWB aircraft is the square cube law. It is a mathematical principle which shows the relationship between the volume and the area as a shape's size increases or decreases. It states that: When an object undergoes a proportional increase in size, its new surface area is proportional to the square of the multiplier and its new volume is proportional to the cube of the multiplier. Essentially, it means that the surface-area-tovolume ratio decreases with increasing volume such that (A $\left.=\mathrm{V}^{2 / 3}\right)$. [4]

This is represented mathematically by: 
$A_{2}=A_{1}\left(l_{2} / l_{1}\right)^{2}$

Where $A_{1}$ is the original surface area and $A_{2}$ is the new surface area.

$V_{2}=V_{1}\left(l_{2} / l_{1}\right)^{3}$

Where $\mathrm{V}_{1}$ is the original volume, $\mathrm{V}_{2}$ is the new volume, $\mathrm{l}_{1}$ is the original length, and $l_{2}$ is the new length. This is important because it shows that though the volume increases, the surface-area-to-volume ratio increases less, which is an advantage. The lower surface area exposed means there will be less skin-friction drag, which is one the major component of drag during cruising flight.

Fig.1.1 shows that while the volume increases $8 x$, the surface area increases just $4 x$. This, when applied to large aircraft design means that there is less wetted area, which in turn means less drag.

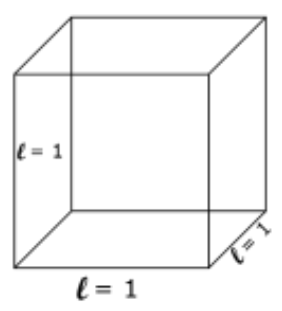

length $=1$ unit volume $=1$ cubic units area $=6$ square units

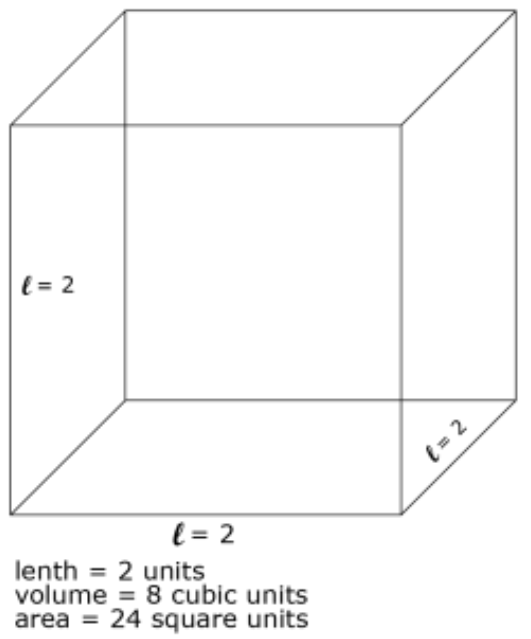

Fig. 1.1 Square Cube Law

\section{CATIA DESIGN OF A TEST MODEL}

The planform geometry was initially created in full scale using AutoCAD 2015as shown in fig. 2.1. The total span of the aircraft is $280 \mathrm{ft}$. This is the distance from wingtip to wingtip. The aspect ratio, which is the ratio of its span to its aerodynamic breadth or chord, is 4.248 . The outer wing taper ratio, which is the ratio of the chord at the tip to the chord at the root, is 0.262 . The total wetted area is 36,904 square feet.

The 3D modeling was done using CATIA V5. The scale used was 1:304. The first part which was modeled was the centerbody as shown in fig.2.1. The centerbody is the feature which makes blended wing body configuration unique. Not only does it house the payload, it also generates lift.

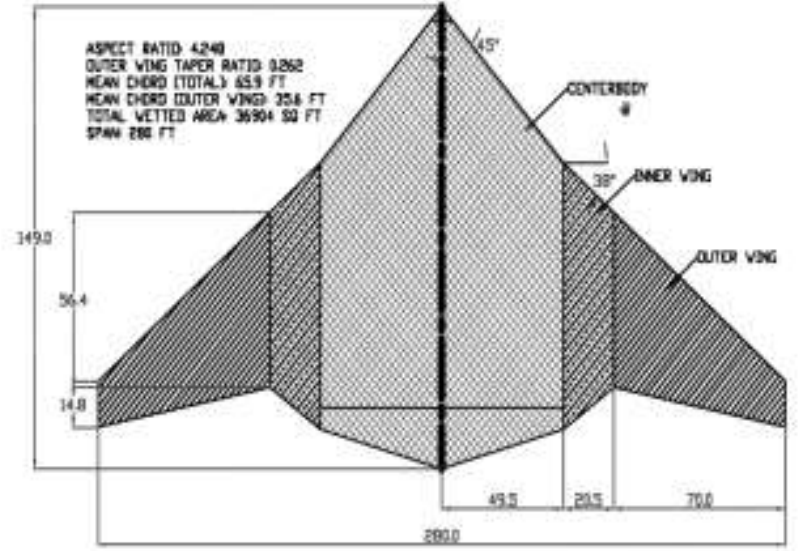

Fig.2.1 Planform View of BWB

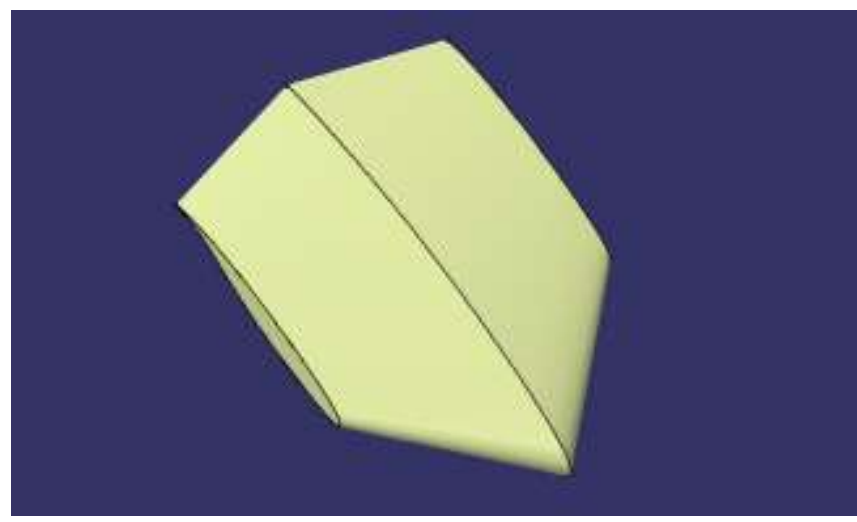

Fig.2.2 BWB Centerbody

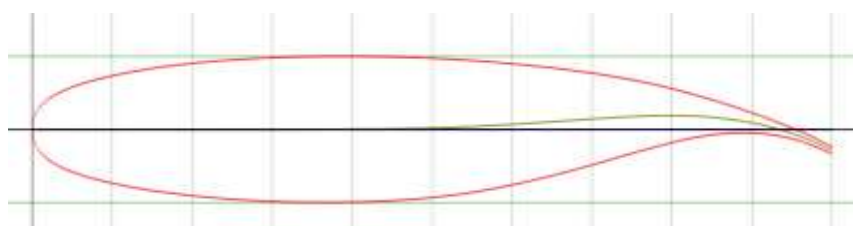

Fig.2.2 shows a closer view of the cross-section of the center body. The shape is that of a NACA 0012-64 airfoil.

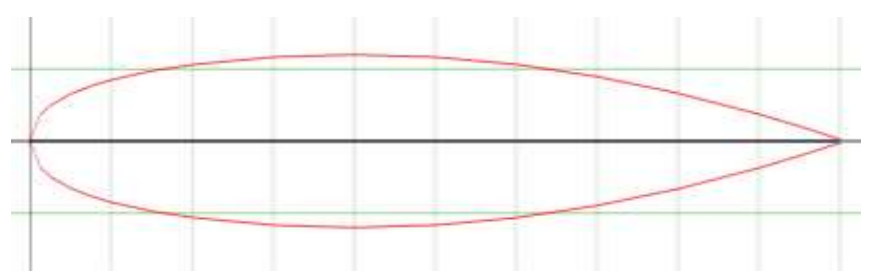

Fig. 2.3. NACA SC(2)-0710 Airfoil

Fig.2.2. shows a closer view of the cross-section of the centerbody. The shape is that of a NACA 0012-64 airfoil. The airfoil used for the wings is NACA SC(2)-0710 as shown in fig.2.3.

The airfoil used for the wings is NACA SC(2)-0710. It is a supercritical airfoil. A supercritical airfoil is an airfoil designed, primarily, to delay the onset of wave drag in the transonic speed range. Supercritical airfoils are characterized by their flattened upper surface, highly cambered aft section, and larger leading edge radius. 


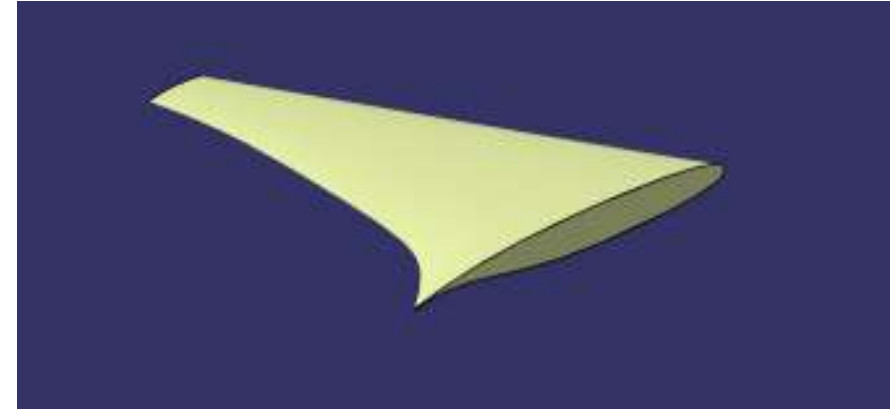

Fig.2.4.BWB Wing

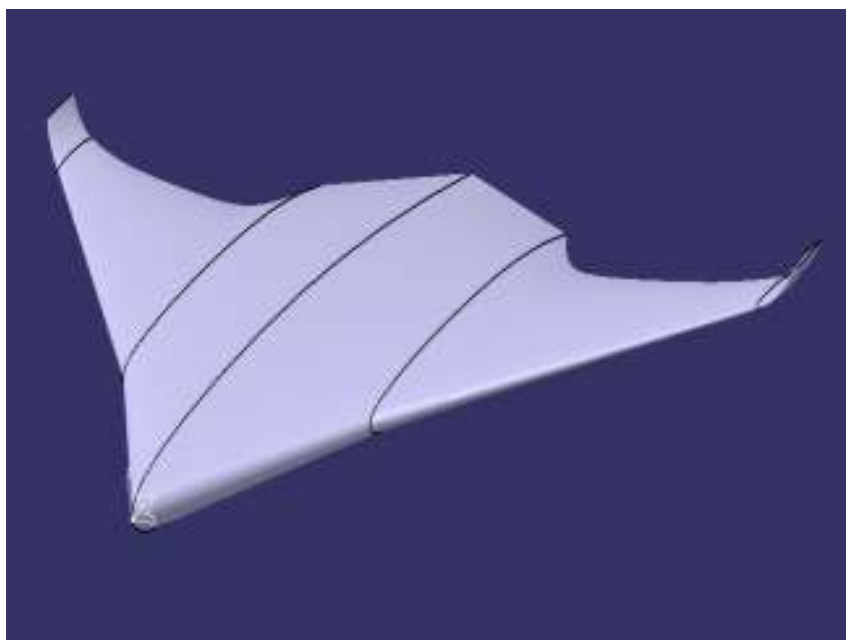

Fig.2.5 winglet

Fig.2.6. shows the final model which has been designed for further analysis. The engines have been omitted from analysis because the focus of this study is on the aerodynamic effect of the overall configuration. Table 1 and 2 shows the inner and outer wing specification details.

Table 1 Details of the specifications of the inner wing

\begin{tabular}{|l|l|}
\hline AIRFOIL TYPE & NACA SC(2)-0710 \\
\hline SWEEP ANGLE & 38 \\
\hline TAPER RATIO & 0.6557 \\
\hline ASPECT RATIO & 0.42 \\
\hline WING AREA & $1000 \mathrm{~mm}^{2}$ \\
\hline MAXIMUM CHORD & $86.01 \mathrm{~mm}$ \\
\hline MINIMUM CHORD & $56.4 \mathrm{~mm}$ \\
\hline WING SPAN & $20.5 \mathrm{~mm}$ \\
\hline
\end{tabular}

Table 2 Details of the specifications of the outer wing

\begin{tabular}{|l|l|}
\hline AIRFOIL TYPE & NACA SC(2)-0710 \\
\hline SWEEP ANGLE & 38 \\
\hline TAPER RATIO & 0.2627 \\
\hline ASPECT RATIO & 2.45 \\
\hline WING AREA & $2000 \mathrm{~mm}^{2}$ \\
\hline MAXIMUM CHORD & $56.4 \mathrm{~mm}$ \\
\hline MINIMUM CHORD & $14.819 \mathrm{~mm}$ \\
\hline WING SPAN & $70 \mathrm{~mm}$ \\
\hline
\end{tabular}

Fig.2.5 shows the view of the winglet. A winglet is a lift augmenting device which is attached at the wing tip of an aircraft. Winglets are used to improve the aerodynamic efficiency of an aircraft by lowering the formation of induced drag which is caused by the wingtip vortices.

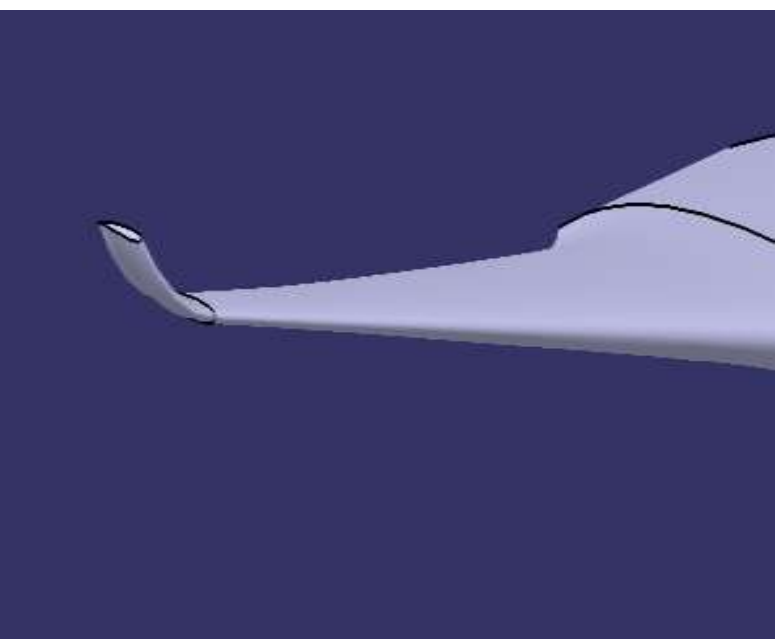

Fig.2.6 Blended Wing Body CATIA Model

\section{CFD ANALYSIS}

The computational fluid dynamics analysis over the blended wing body model is carried out in ANSYS Fluent. The flow over the aircraft is analyzed at $0^{\circ}, 5^{\circ}, 10^{\circ}, 20^{\circ}, 30^{\circ}$ and $35^{\circ}$ angle of attack. Angle of attack (AOA) is the angle between the chord line and the relative wind. The free stream velocity is $50 \mathrm{~m} / \mathrm{s}$ and inviscid flow model is used.

The computational domain size was taken as 6 times the dimensions of the model. The values are given in Table 3 and the mesh details in Table 4.

Table 3 Domain Size

\begin{tabular}{|l|l|}
\hline$+X$ Value & $840 \mathrm{~mm}$ \\
\hline+ Y Value & $450 \mathrm{~mm}$ \\
\hline$+Z$ Value & $300 \mathrm{~mm}$ \\
\hline$-X$ Value & $840 \mathrm{~mm}$ \\
\hline$-Y$ Value & $450 \mathrm{~mm}$ \\
\hline$-Z$ Value & $300 \mathrm{~mm}$ \\
\hline
\end{tabular}

Table 4: Mesh Details

\begin{tabular}{|l|l|}
\hline Number of Nodes & 342434 \\
\hline $\begin{array}{l}\text { Number of Elements } \\
\text { (Tetrahedral) }\end{array}$ & 1954759 \\
\hline
\end{tabular}




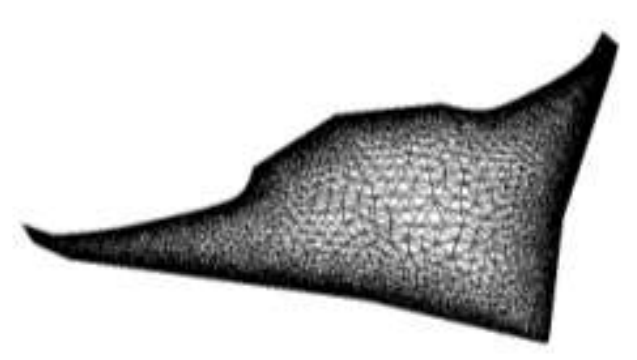

Fig.3.1 Mesh on Body

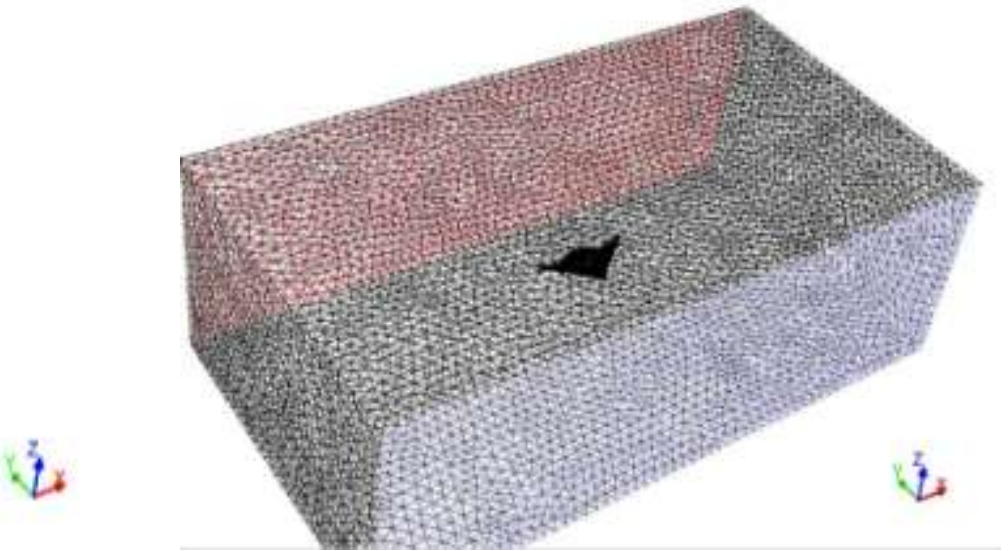

Fig.3.2 Mesh in the domain

The mesh over the body is shown in Fig. 3.1, and Fig.3.2 shows the mesh in the domain.

\section{RESULTS}

This section includes the results of simulations. The static pressure and velocity on the upper and lower surfaces at various angles of attack are presented.

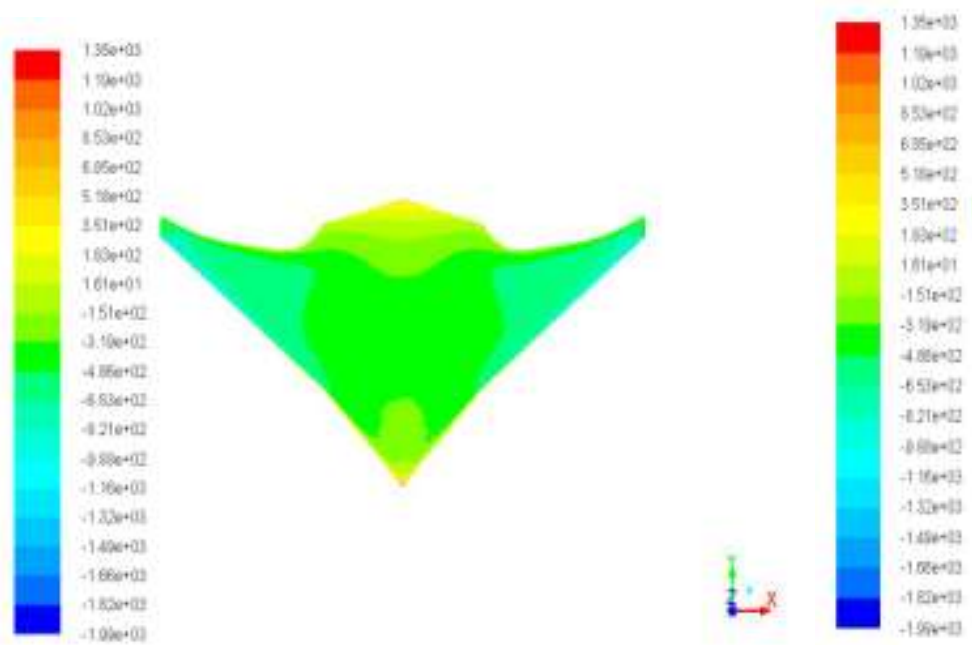

Fig.4.1 Contours of Static Pressure (Pascal) - Upper Surface and Lower surface $\left(0^{\circ}\right.$ AOA)
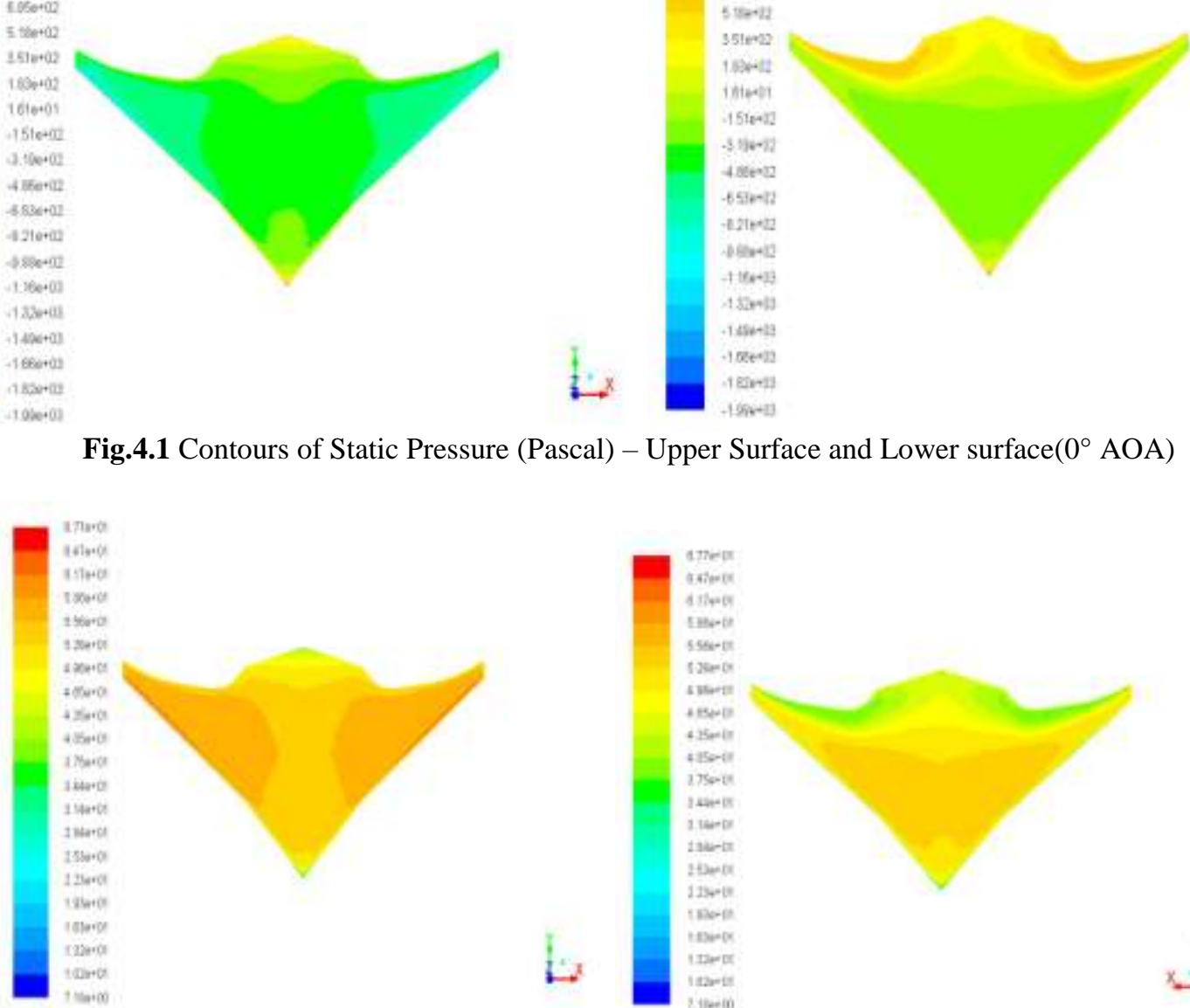

Fig.4.2 Contours of Velocity Magnitude (m/s) - Upper Surface and Lower surface $\left(0^{\circ} \mathrm{AOA}\right)$ 
Table 5 Static Pressure - Upper Surface\& Lower Surface

\begin{tabular}{|l|l|l|}
\multicolumn{2}{c}{$\left(0^{\circ} \mathrm{AOA}\right)$} \\
\hline & $\begin{array}{l}\text { Upper } \\
\text { Surface }\end{array}$ & $\begin{array}{l}\text { Lower } \\
\text { Surface }\end{array}$ \\
\hline Maximum Value & $1350 \mathrm{~Pa}$ & $1350 \mathrm{~Pa}$ \\
\hline Minimum Value & $-1490 \mathrm{~Pa}$ & $-319 \mathrm{~Pa}$ \\
\hline
\end{tabular}

Table 6 Velocity - Upper Surface \& Lower Surface $\left(0^{\circ}\right.$

\begin{tabular}{|l|l|l|}
\hline \multicolumn{1}{|c|}{ AOA) } \\
& $\begin{array}{l}\text { Upper } \\
\text { Surface }\end{array}$ & $\begin{array}{l}\text { Lower } \\
\text { Surface }\end{array}$ \\
\hline Maximum Value & $64.7 \mathrm{~m} / \mathrm{s}$ & $55.6 \mathrm{~m} / \mathrm{s}$ \\
\hline Minimum Value & $34.4 \mathrm{~m} / \mathrm{s}$ & $34.4 \mathrm{~m} / \mathrm{s}$ \\
\hline
\end{tabular}

From the previous figures, we can see that the pressure is higher on the lower surface and lower on the upper surface, even at $0^{\circ}$ angle of attack. Therefore there is a net force, i.e. lift is generated. Tables 5 list out the maximum and minimum pressure values on the upper and lower surfaces respectively, at $0^{\circ}$ angles of attack. Tables 6 list out the maximum and minimum values of velocity on the upper and lower surface, respectively, at $0^{\circ}$ angles of attack.

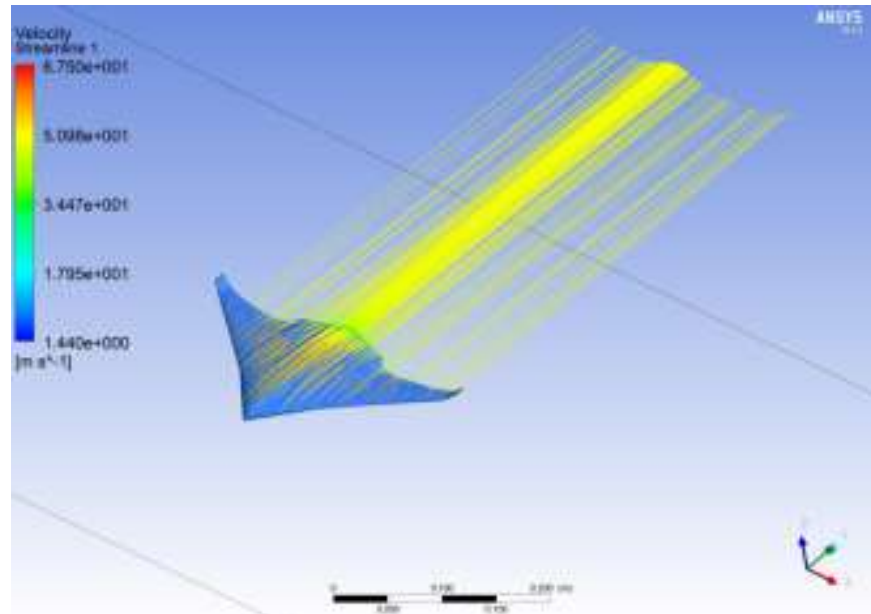

Fig. 4.3 Streamline flow over Body

Fig.4.3 shows the streamline flow over the body. Streamlines are a family of curves that are instantaneously tangent to the velocity vector of the flow. The figure shows clearly how the flow is accelerating over the upper surface.

Next, the flow was analyzed at $5^{\circ}$ angle of attack, followed by $10^{\circ}, 20^{\circ}, 30^{\circ}$ and $35^{\circ}$ angle of attack

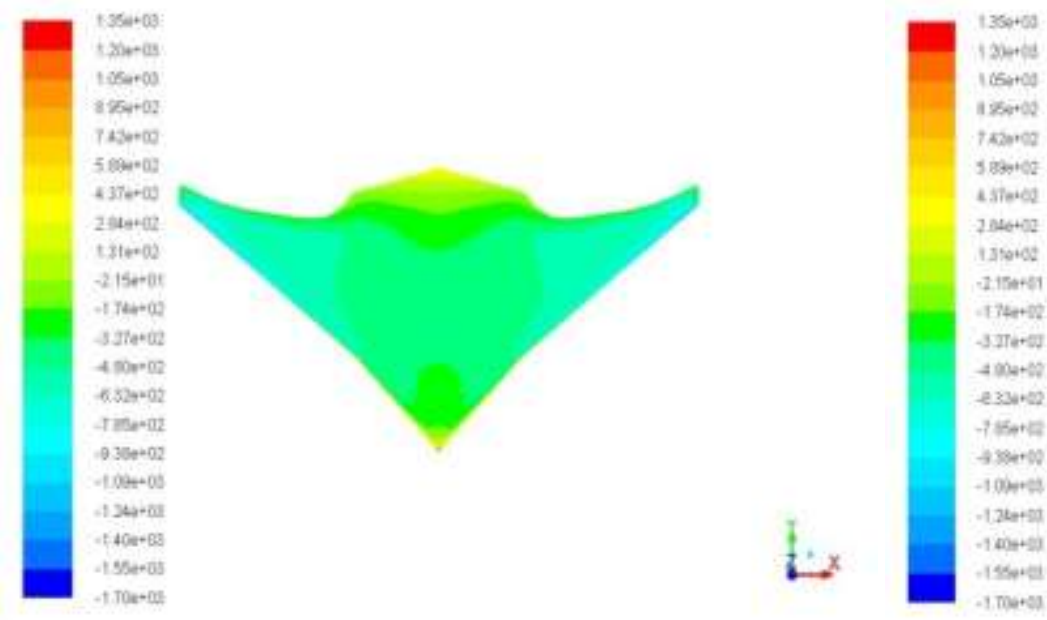

Fig 4.4 Contours of Static Pressure (pascal) - Upper Surface \& Lower Surface $\left(5^{\circ}\right.$ AOA)
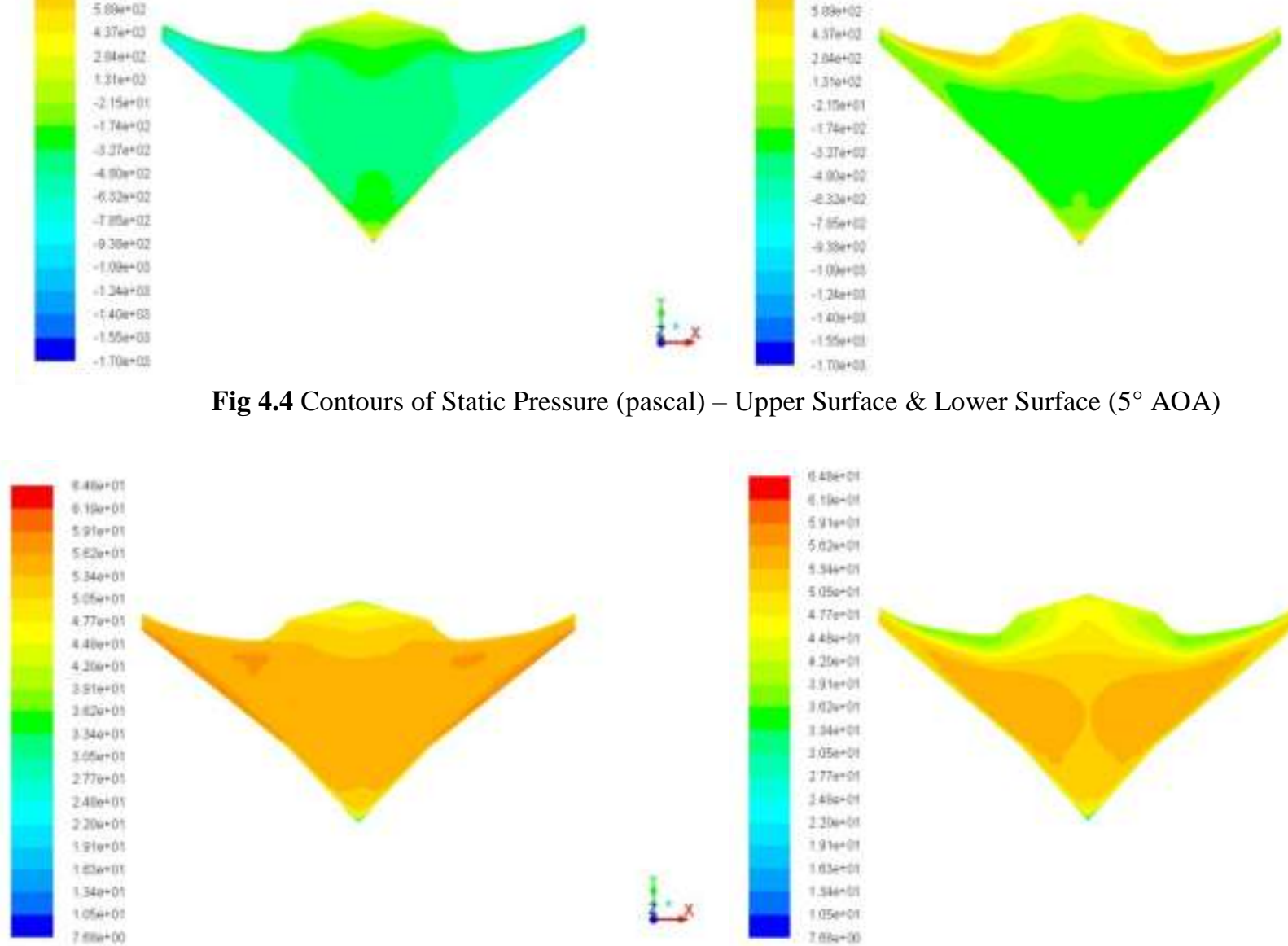

Fig 4.5 Contours of Velocity Magnitude (m/s) - Upper Surface $\left(5^{\circ}\right.$ AOA) 
Table 7 Static Pressure - Upper Surface and Lower Surface

\begin{tabular}{|l|l|l|}
\multicolumn{1}{l|}{$\left(5^{\circ} \mathrm{AOA}\right)$} \\
\hline Maximum Value & Upper Surface & Lower surface \\
\hline Minimum Value & $1220 \mathrm{~Pa}$ & $1350 \mathrm{~Pa}$ \\
\hline & $-1550 \mathrm{~Pa}$ & $-327 \mathrm{~Pa}$ \\
\hline
\end{tabular}

Table 8 Velocity - Upper Surface\& Lower Surface $\left(5^{\circ}\right.$

\begin{tabular}{|l|l|l|}
\hline \multicolumn{1}{|c|}{ AOA) } \\
\hline Maximum Value & $64.8 \mathrm{~m} / \mathrm{s}$ & $59.1 \mathrm{~m} / \mathrm{s}$ \\
\hline Minimum Value & $39.1 \mathrm{~m} / \mathrm{s}$ & $33.4 \mathrm{~m} / \mathrm{s}$ \\
\hline
\end{tabular}

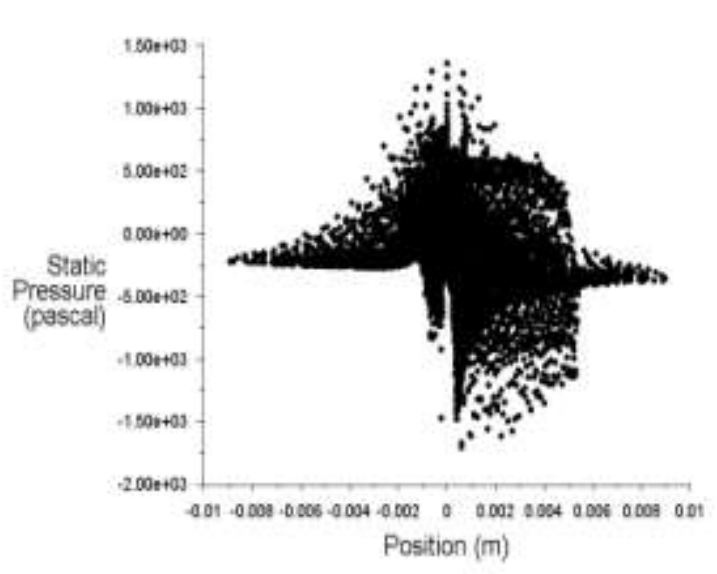

Fig. 4.6 Static Pressure Plot $\left(5^{\circ} \mathrm{AOA}\right)$
After the angle of attack has been increased, the pressure on the upper surface decreases and the pressure on the lower surface slightly increases. Table 7 list out the maximum and minimum pressure values on the upper and lower surfaces respectively, at $5^{\circ}$ angles of attack. Table 8 list out the maximum and minimum values of velocity on the upper and lower surface, respectively, at $5^{\circ}$ angles of attack.

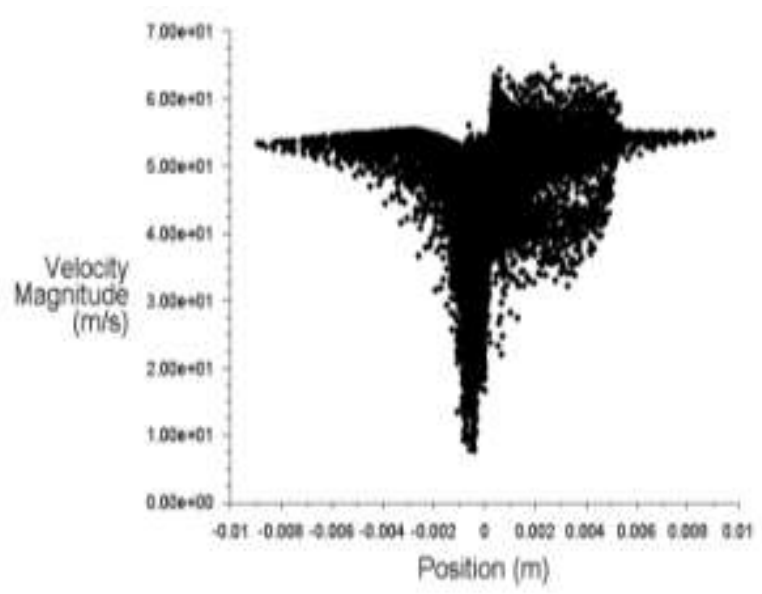

Fig. 4.7 Velocity Magnitude Plot (5 AOA)
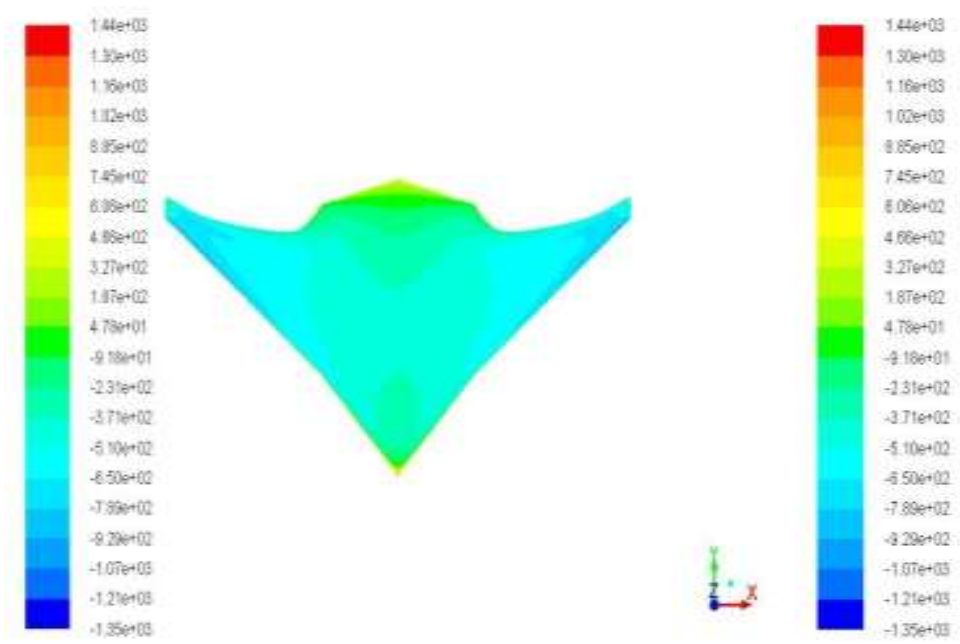

Fig.4.8 Contours of Static Pressure (pascal) - Upper Surface \& Lower Surface $\left(10^{\circ}\right.$ AOA)

Table 9 Static Pressure - Upper Surface \& Lower Surface $\left(10^{\circ}\right.$ AOA)

\begin{tabular}{|l|l|l|}
\hline & $\begin{array}{l}\text { Upper } \\
\text { surface }\end{array}$ & $\begin{array}{l}\text { Lower } \\
\text { surface }\end{array}$ \\
\hline Maximum Value & $1160 \mathrm{~Pa}$ & $1300 \mathrm{~Pa}$ \\
\hline Minimum Value & $-1210 \mathrm{~Pa}$ & $-510 \mathrm{~Pa}$ \\
\hline
\end{tabular}




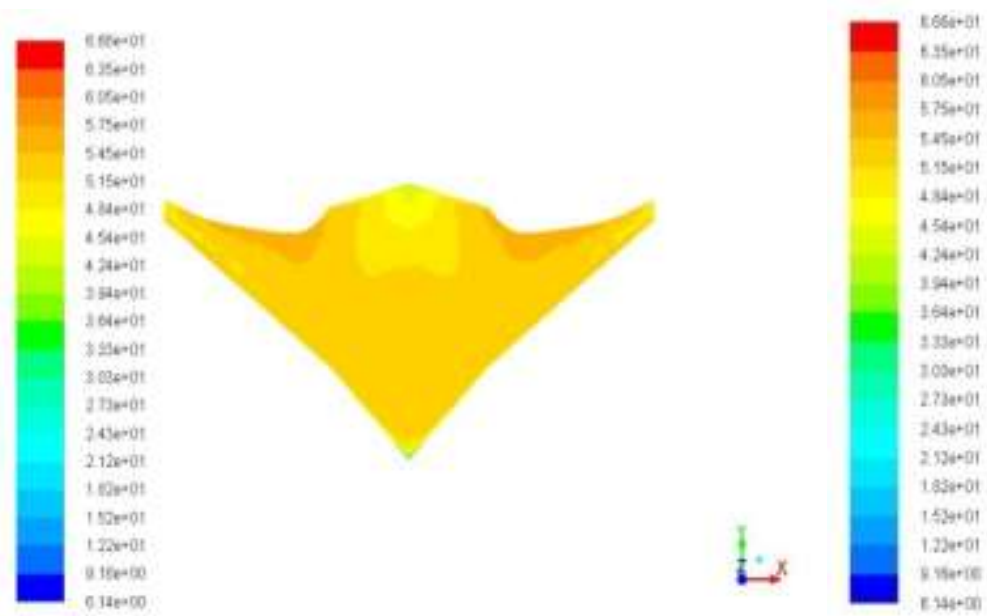

Fig.4.9 Contours of Velocity Magnitude (m/s) - Upper Surface \& Lower Surface $\left(10^{\circ}\right.$ AOA)

Table 10. Velocity (m/s) - Upper Surface \& Lower Surface

\begin{tabular}{|l|l|l|}
\hline & $\left(10^{\circ}\right.$ AOA $)$ \\
\hline Maximum Value & Upper surface & Lower surface \\
\hline Minimum Value & $57.5 \mathrm{~m} / \mathrm{s}$ & $63.5 \mathrm{~m} / \mathrm{s}$ \\
\hline
\end{tabular}

Increasing the angle of attack to $10^{\circ}$, the pressure on the upper surface continues to decrease. Table 9 list out the maximum and minimum pressure values on the upper and lower surfaces respectively, at $10^{\circ}$ angles of attack. Table 10 list out the maximum and minimum values of velocity on the upper and lower surface, respectively, at $10^{\circ}$ angles of attack.
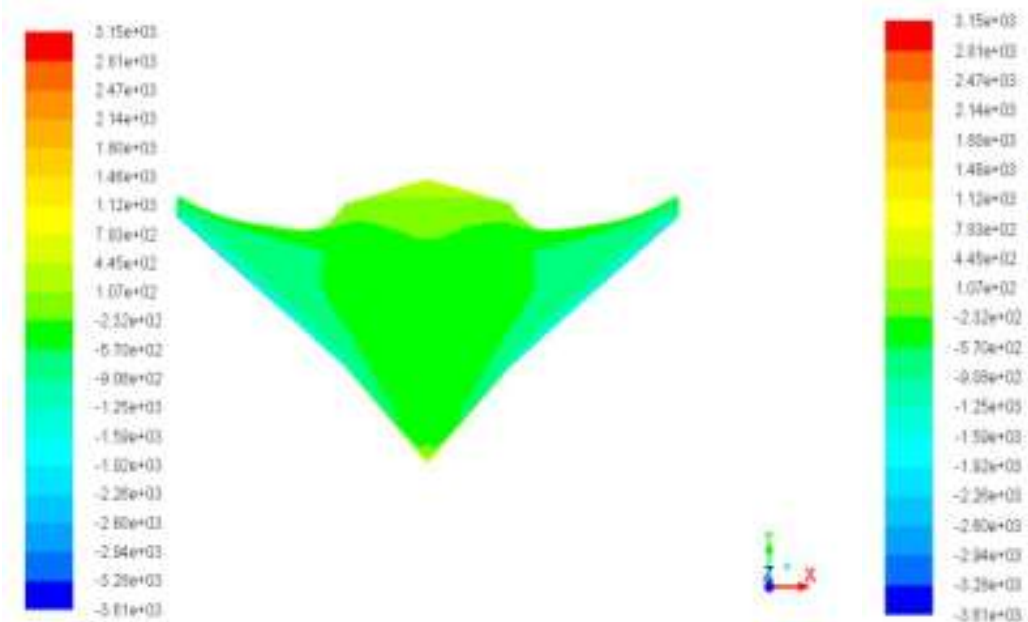

Fig.4.10 Contours of Static Pressure (pascal) - Upper Surface \& Lower Surface $\left(20^{\circ}\right.$ AOA)
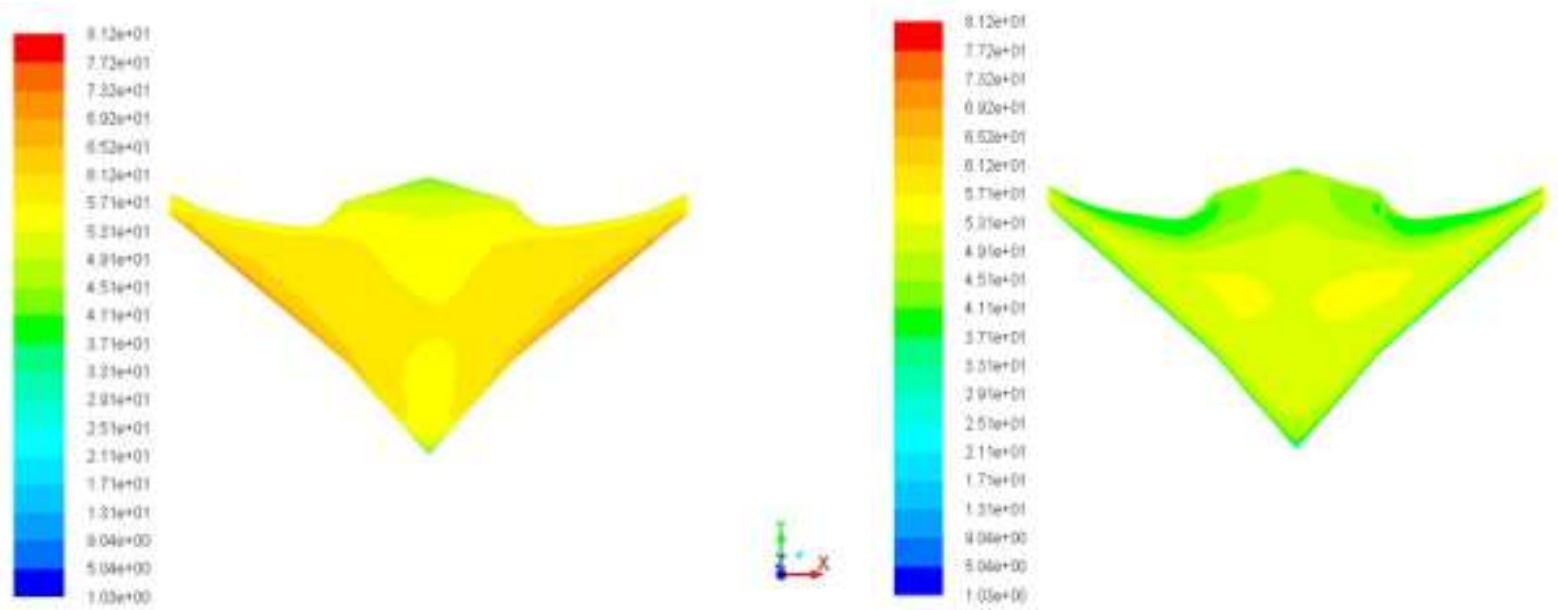

Fig.4.11 Contours of Velocity Magnitude (m/s) - Upper Surface \& Lower Surface $\left(20^{\circ}\right.$ AOA) 
Table 11 Static Pressure - Upper Surface \& Lower Surface (20 AOA)

\begin{tabular}{|l|l|l|}
\hline & Upper Surface & $\begin{array}{l}\text { Lower } \\
\text { Surface }\end{array}$ \\
\hline $\begin{array}{l}\text { Maximum } \\
\text { Value }\end{array}$ & $783 \mathrm{~Pa}$ & $1120 \mathrm{~Pa}$ \\
\hline $\begin{array}{l}\text { Minimum } \\
\text { Value }\end{array}$ & $-2940 \mathrm{~Pa}$ & $107 \mathrm{~Pa}$ \\
\hline
\end{tabular}
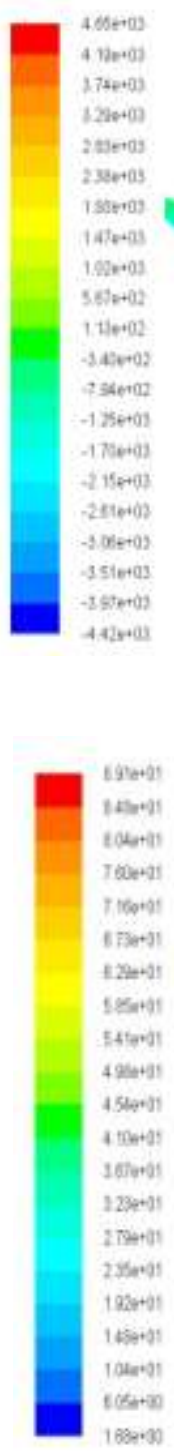

Table 12 Velocity- Upper Surface \& Lower Surface $\left(20^{\circ}\right.$ AOA)

\begin{tabular}{|l|l|l|}
\hline & Upper Surface & $\begin{array}{l}\text { Lower } \\
\text { Surface }\end{array}$ \\
\hline $\begin{array}{l}\text { Maximum } \\
\text { Value }\end{array}$ & $73.2 \mathrm{~m} / \mathrm{s}$ & $61.2 \mathrm{~m} / \mathrm{s}$ \\
\hline $\begin{array}{l}\text { Minimum } \\
\text { Value }\end{array}$ & $41.1 \mathrm{~m} / \mathrm{s}$ & $29.1 \mathrm{~m} / \mathrm{s}$ \\
\hline
\end{tabular}

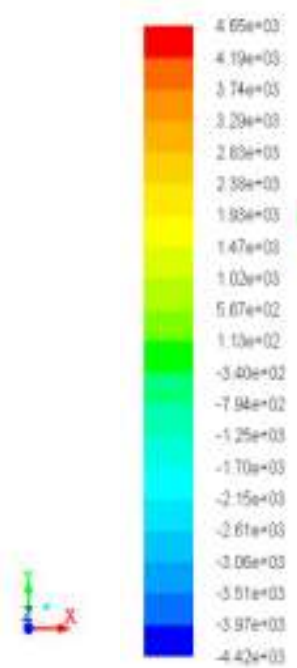

$42 x-0.0$

Fig.4.12 Contours of Static Pressure (pascal) - Upper Surface \&Lower surface $\left(30^{\circ} \mathrm{AOA}\right)$

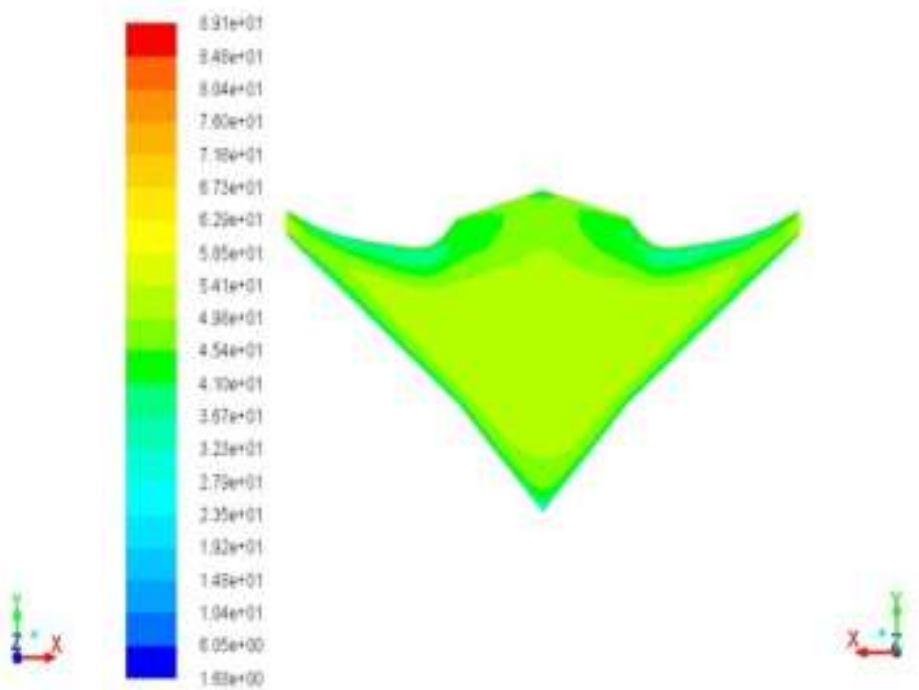

Fig.4.13 Contours of Velocity Magnitude (m/s) - Upper Surface \& Lower Surface $\left(30^{\circ}\right.$ AOA)

Table 13 Static Pressure - Upper Surface \& Lower Surface $\left(30^{\circ} \mathrm{AOA}\right)$

\begin{tabular}{|l|l|l|}
\hline & Upper Surface & Lower Surface \\
\hline Maximum Value & $1020 \mathrm{~Pa}$ & $1470 \mathrm{~Pa}$ \\
\hline Minimum Value & $-4420 \mathrm{~Pa}$ & $113 \mathrm{~Pa}$ \\
\hline
\end{tabular}

Table 13 list out the maximum and minimum pressure values on the upper and lower surfaces respectively, at $30^{\circ}$ angles of attack. Tables 14 list out the maximum and minimum values of velocity on the upper and lower surface, respectively, at $30^{\circ}$ angles of attack.

Table 14 Velocity - Upper Surface \& Lower Surface $\left(30^{\circ}\right.$

$$
\text { AOA) }
$$

\begin{tabular}{|l|l|l|}
\hline & Upper Surface & Lower Surface \\
\hline Maximum Value & $80.4 \mathrm{~m} / \mathrm{s}$ & $58.5 \mathrm{~m} / \mathrm{s}$ \\
\hline Minimum Value & $45.4 \mathrm{~m} / \mathrm{s}$ & $23.5 \mathrm{~m} / \mathrm{s}$ \\
\hline
\end{tabular}




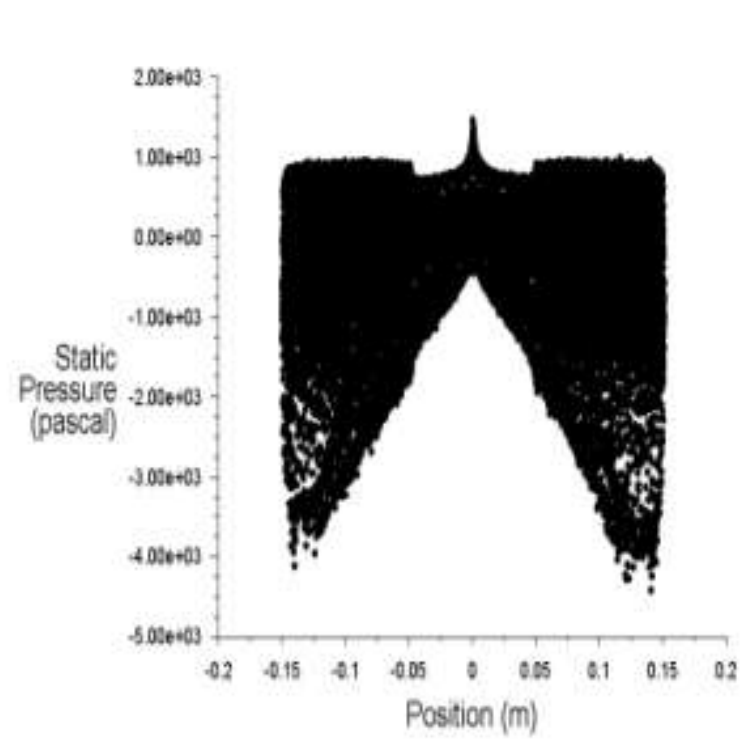

Fig. 4.14 Static Pressure Plot $\left(30^{\circ}\right.$ AOA)

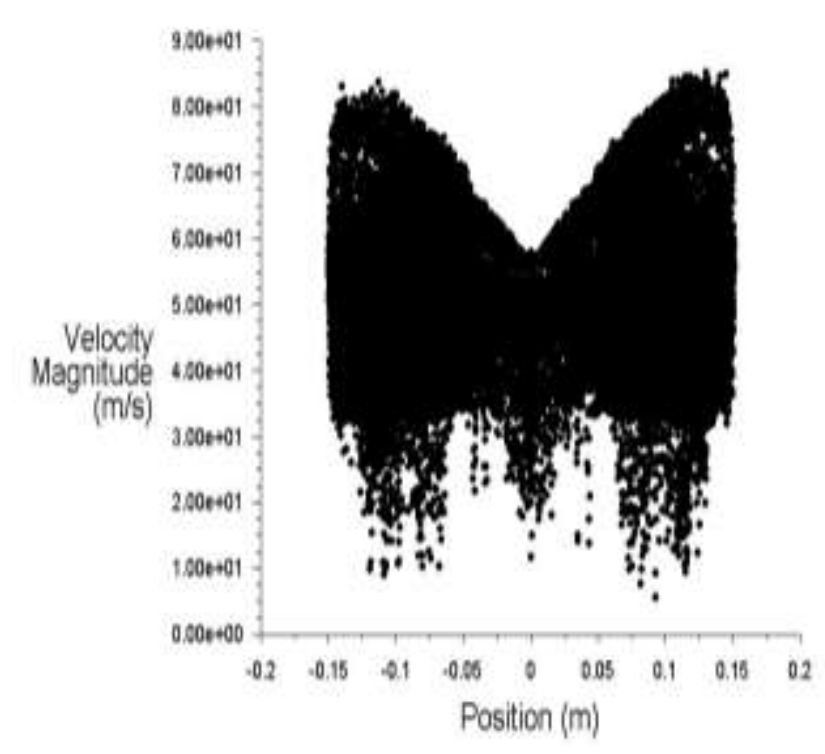

Fig.4.15 Velocity Magnitude Plot $\left(30^{\circ}\right.$ AOA)
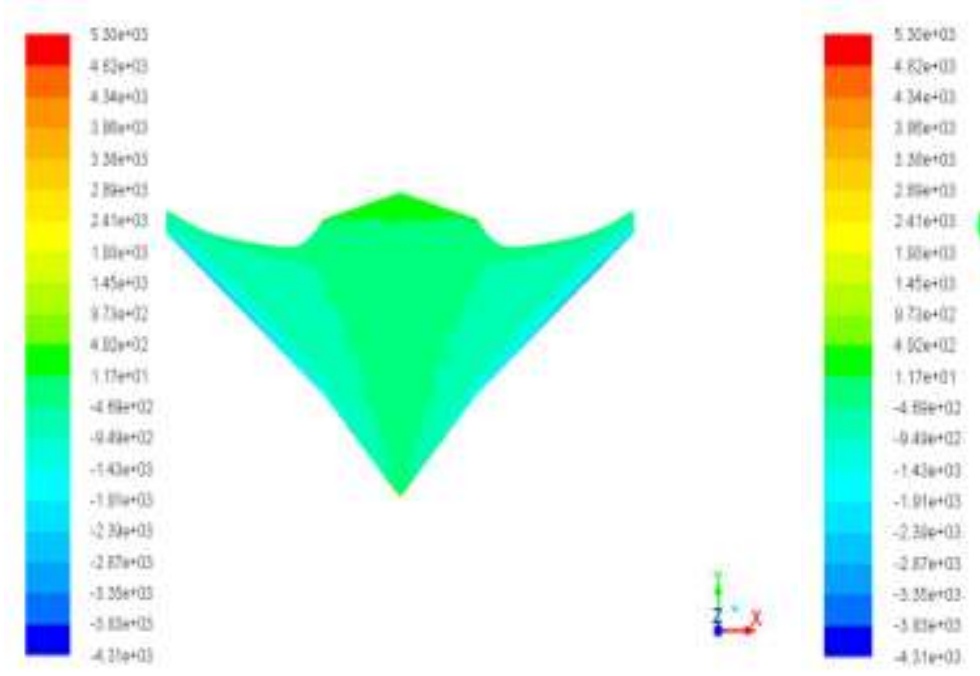

Fig. 4.16 Contours of Static Pressure (pascal) - Upper Surface \& Lower Surface $\left(35^{\circ}\right.$ AOA)
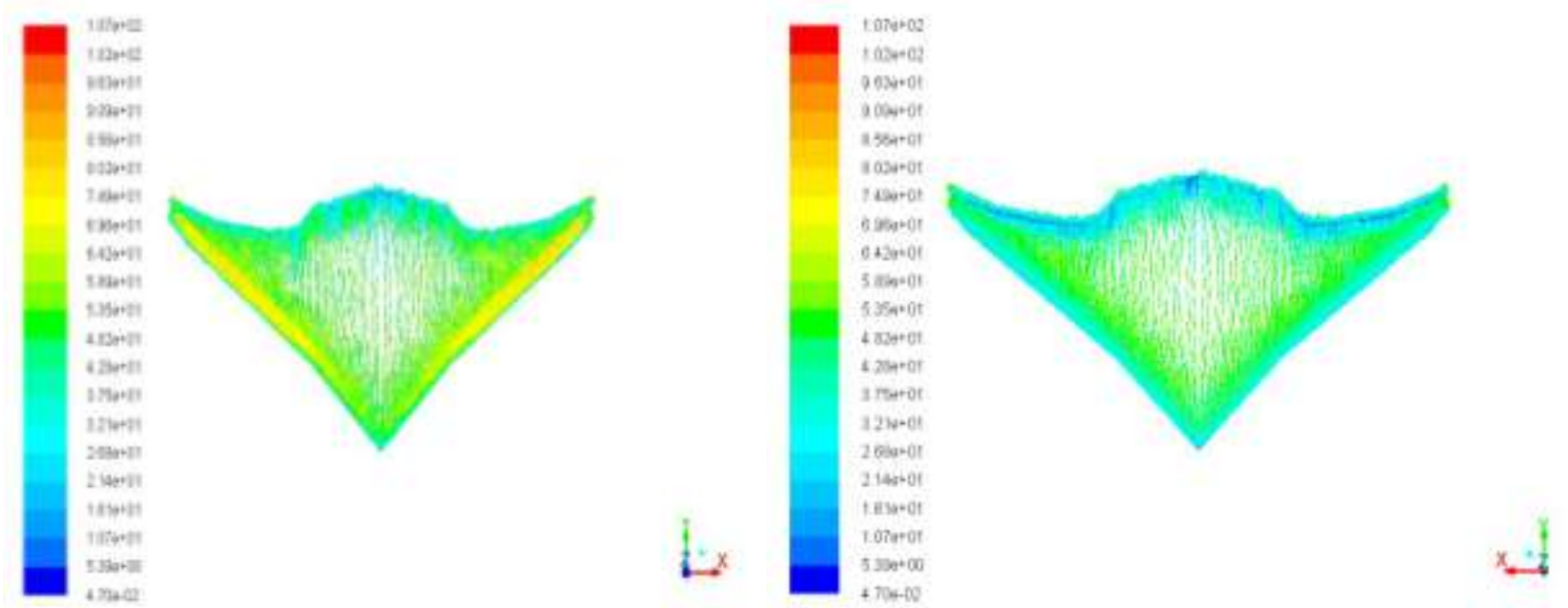

Fig. 4.17 Velocity Vectors - Upper Surface \& Lower Surface $\left(35^{\circ}\right.$ AOA) 


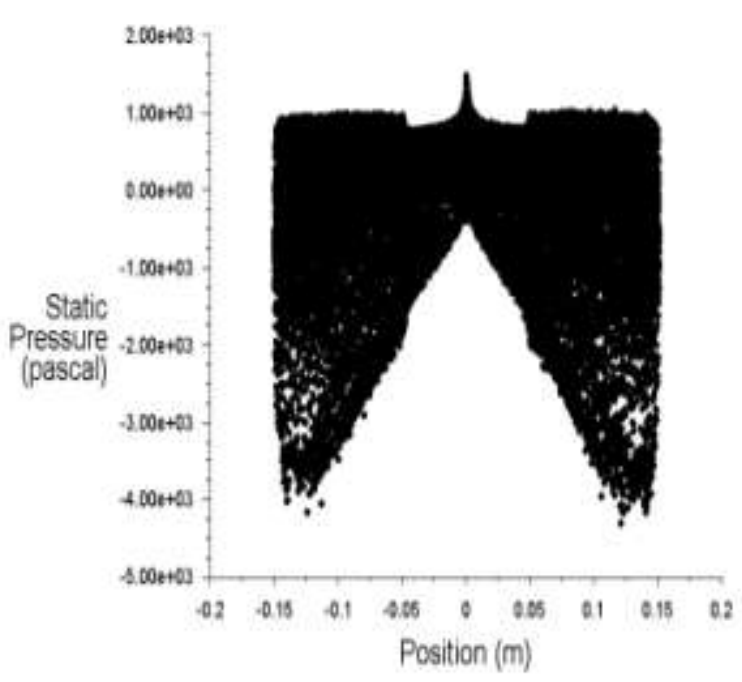

Fig. 4.18 Static Pressure Plot $\left(35^{\circ}\right.$ AOA)

The force values obtained from Fluent are used to obtain the coefficients of lift and drag, by the following equations:

$$
\begin{aligned}
& F_{L}=F_{y} \cos \left(a_{\infty}\right)-F_{x} \sin \left(a_{\infty}\right) \ldots \ldots \ldots \ldots \ldots \ldots \ldots \ldots \ldots \ldots \ldots \ldots \ldots \\
& F_{D}=F_{y} \sin \left(a_{\infty}\right)+F_{x} \cos \left(a_{\infty}\right) \ldots \ldots \ldots \ldots \ldots \ldots
\end{aligned}
$$

$$
\begin{gathered}
C_{L}=\frac{2 F_{L}}{\frac{1}{2} \rho V^{2} S} \ldots \ldots \ldots \ldots \ldots \ldots . . . \\
C_{D}=\frac{2 F_{D}}{\frac{1}{2} \rho V^{2} S} \ldots \ldots \ldots \ldots \ldots \\
C_{M}=\frac{2 T_{Z}}{\frac{1}{2} \rho V^{2} S_{r e f} l_{r e f}} \ldots \ldots . \\
C_{N \alpha}=\frac{C_{N\left(\alpha_{2}\right)}-C_{N\left(\alpha_{1}\right)}}{\alpha_{2}-\alpha_{1}} \ldots \\
C_{M \alpha}=\frac{C_{M\left(\alpha_{2}\right)}-C_{M\left(\alpha_{1}\right)}}{\alpha_{2}-\alpha_{1}}
\end{gathered}
$$

Where $a_{\infty}$ is the freestream angle of attack, $\mathrm{F}_{\mathrm{x}}$ is the force coefficient in the $\mathrm{x}$-direction, $\mathrm{F}_{\mathrm{y}}$ is the force coefficient in the $y$-direction, $C_{M}$ is the coefficient of pitching moment, $C_{L}$ is the coefficient of lift on the $\mathrm{BWB}$, and $\mathrm{C}_{\mathrm{D}}$ is the drag coefficient of the BWB. Here, $\rho$ is the density, $\mathrm{V}$ is the freestream velocity, $\mathrm{q}$ is the dynamic pressure and $\mathrm{S}$ is the reference area. The results of the simulation and subsequent calculations are tabulated below.

Table 15 Results

\begin{tabular}{|l|l|l|l|l|l|l|l|}
\hline AOA & Lift Force & Drag Force & $\mathbf{L} / \mathbf{D}$ & $\mathbf{q}$ & $\mathbf{C}_{\mathbf{L}}$ & $\mathbf{C}_{\mathbf{D}}$ & $\mathbf{C}_{\mathbf{L}} / \mathbf{C}_{\mathbf{D}}$ \\
\hline 0 & 7.3017073 & 0.21570344 & 33.85068 & 30.625 & 0.476846 & 0.014087 & 33.85068 \\
\hline 5 & 7.2883024 & 0.21987066 & 33.14814 & 30.625 & 0.475971 & 0.014359 & 33.14814 \\
\hline 10 & 8.4450731 & 0.23986918 & 35.207 & 30.625 & 0.551515 & 0.015665 & 35.207 \\
\hline 20 & 12.46522 & 0.26142903 & 47.68109 & 30.625 & 0.814055 & 0.017073 & 47.68109 \\
\hline 30 & 14.175381 & 0.38958372 & 36.38597 & 30.625 & 0.925739 & 0.025442 & 36.38597 \\
\hline 35 & 13.996711 & 0.39171392 & 35.73197 & 30.625 & 0.914071 & 0.025581 & 35.73197 \\
\hline
\end{tabular}

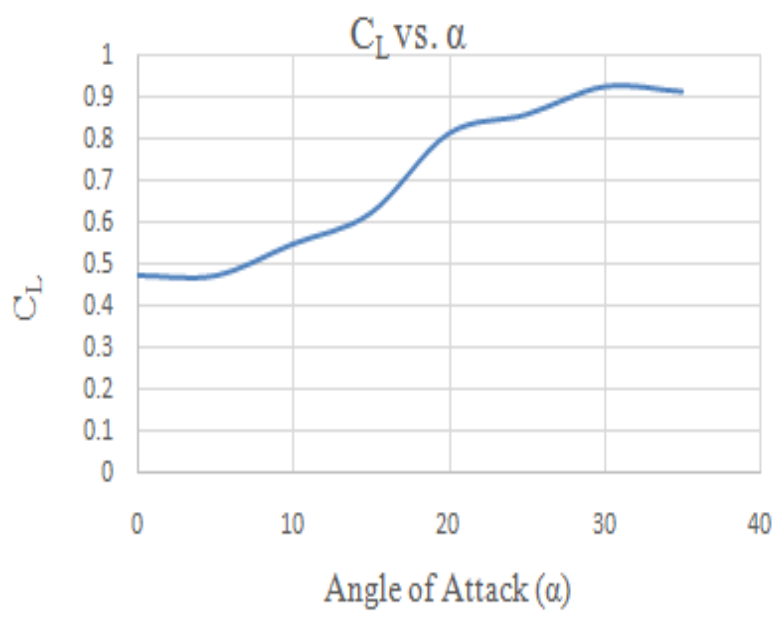

Fig.4.19 $C_{L}$ vs. $\alpha$ Plot

Fig. 4.19 shows the variation of lift coefficient $\left(C_{L}\right)$ for different values of angle of attack $(\alpha)$. For the given free stream speed, the value of $C_{L}$ increases as the angle of attack is increased until its maximum value at around $\alpha=33^{\circ}$ and decreases afterwards.

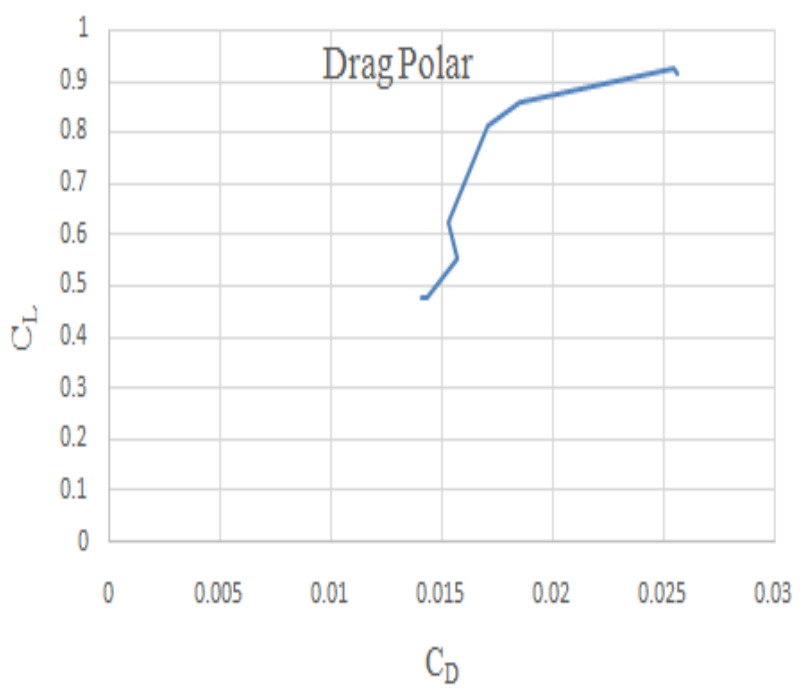

Fig.4.20 $C_{L}$ vs. $C_{D}$ Plot 
The drag polar $\left(\mathrm{C}_{\mathrm{L}}\right.$ versus $\left.\mathrm{C}_{\mathrm{D}}\right)$ curve can be seen in Fig.4.20 The drag polar is the relationship between the lift on an aircraft and its drag, expressed in terms of the dependence of the lift coefficient on the drag coefficient. The significant aerodynamic properties of aircraft wings are summarized by two dimensionless quantities, the lift and drag coefficients, $\mathrm{C}_{\mathrm{L}}$ and $\mathrm{C}_{\mathrm{D}}$. The lift and the drag forces, $\mathrm{L}$ and $\mathrm{D}$ are scaled by the same factor, so as to make the comparison more effective. Figure 4.21 shows how the $C_{L} / C_{D}$ varies with the angle of attack.

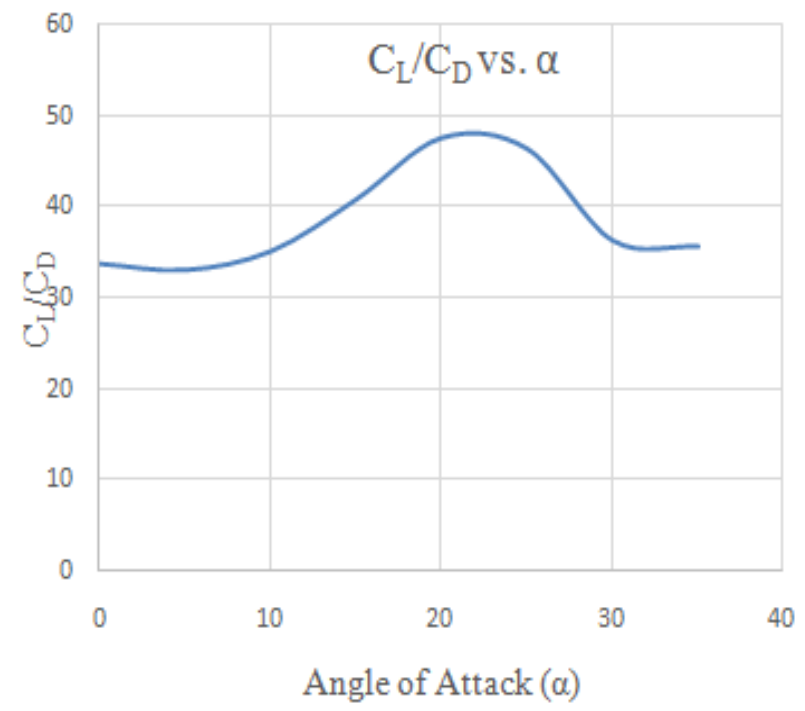

Fig. 4.21 $C_{L} / C_{D}$ vs. $\alpha$ Plot

The drag polar $\left(C_{L}\right.$ versus $\left.C_{D}\right)$ curve can be seen in Fig.4.20. The drag polar is the relationship between the lift on an aircraft and its drag, expressed in terms of the dependence of the lift coefficient on the drag coefficient. The significant aerodynamic properties of aircraft wings are summarized by two dimensionless quantities, the lift and drag coefficients, $\mathrm{C}_{\mathrm{L}}$ and $\mathrm{C}_{\mathrm{D}}$. The lift and the drag forces, $\mathrm{L}$ and $\mathrm{D}$ are scaled by the same factor, so as to make the comparison more effective. Fig. 4.21 shows how the $C_{L} / C_{D}$ varies with the angle of attack.

The lift-to-drag ratio (L/D) is a very significant parameter to pay attention to during the design process. It is the amount of lift generated by a wing or vehicle, divided by the aerodynamic drag it creates by moving through the air. A higher or more favorable L/D ratio is typically one of the major goals in aircraft design; since a particular aircraft's required lift is set by its weight, delivering that lift with lower drag leads directly to better fuel economy in aircraft, climb performance, and glide ratio.

This can be explained in another way. During straight and level flight condition, the four main forces acting on the airplane are in equilibrium, i.e. lift, weight, drag and thrust. A higher lift means that more weight is allowable, which in turn means a higher payload capacity (which is very important for transport aircraft). A lower drag value means less thrust will be required and hence lower fuel consumption (which is often the operators' largest operating cost).
Hence it has been established that the lift-to-drag ratio is a very important one, and will be the basis of comparison between the blended wing body and conventional configurations.

Table 16 L/D Ratio Comparison

\begin{tabular}{|l|l|}
\hline Aircraft & L/D Ratio \\
\hline Boeing 747 & 17.7 \\
\hline Lockheed U-2 & 25.6 \\
\hline Rutan Voyager & 27 \\
\hline Virgin Atlantic GlobalFlyer & 37 \\
\hline BWB Design & 33.85 \\
\hline
\end{tabular}

The above table details the lift-to-drag ratio of various aircraft at cruise condition. Virgin Atlantic Global Flyer has the highest L/D ratio of 37[6,9]. It is an aircraft which was designed to fly nonstop around the world. The Rutan Voyager had the same purpose, and it was the first aircraft to achieve this goal. For this particular requirement, the airplanes were designed without having to give consideration to payload[7]. The Boeing 747 provides a better comparison. It is a high-capacity, wide-body commercial airliner and has an L/D ratio of 17.7 The Blended Wing Body configurations has achieved almost double that value.

\section{VALIDATION}

The results which were obtained have been validated with reference paper [8].The below table shows the resultant liftto-drag ratio at cruise.

Table 17 Result Validation

\begin{tabular}{|l|c|}
\hline RESULT & L/D \\
VALIDATION & 28.60 \\
\hline Reference Model & 33.85 \\
\hline Designed Model & \\
\hline
\end{tabular}

The results obtained from the reference paper and the results from our designed model are tabulated and an observation is made that the results are nearly matching. Although both models are blended wing body configurations, there are differences in the specific design, hence the variation in results can be expected.

\section{CONCLUSION}

Through the analysis, it has been found that the blended wing body can obtain better efficiency and high performance at subsonic speeds. The drafted design was analyzed and validated with the results of the reference papers. The lift generated by the blended wing body was found to be more than the conventional aircrafts. There was also a reduction in drag for the BWB. One of the most significant differences between conventional aircrafts and the BWB is that the body or the fuselage of the BWB generates lift which was confirmed by the analysis of the center body. 
With BWB having a higher (L/D) ratio and the properties mentioned previously, it truly has the potential to be the future of subsonic transport.

\section{REFERENCES}

[1] R. Devaraju, R. Naveen Kumar, J. Naresh, Computational Aerodynamic Analysis of Blended Wing Body Aircraft, International Research Journal of Engineering and Technology, Volume: 02, Issue: 05,2015

[2] Michael Farrow, Wing Embedded Engines for Large Blended Wing Body Aircraft, A Computational Investigation, University of Surrey, 2009.

[3] ZhoujieLyu and Joaquim R. R. A. Martins, Aerodynamic Design Optimization Studies of a Blended-Wing-Body Aircraft, Journal of Aircraft, 2013

[4] R.H. Liebeck, Design of the Blended Wing Body Subsonic Transport, Journal of Aircraft, Vol. 41, No. 1, 2004.

[5] Spiridon Siouris and Ning Qin, Study of the effects of wing sweep on the aerodynamic performance of a blended wing body aircraft, Proceedings of the Institution of Mechanical Engineers Part G Journal of Aerospace Engineering, 2007.

[6] Hassan Muneel Syed, M. Saqib Hameed, and Irfan A. Manarvi, A Review of Swept and Blended Wing Body Performance Utilizing Experimental, FE and Aerodynamic Techniques, International Journal of Recent Research and Applied Studies,2011.

[7] Tung Wan andHei Yang, Aerodynamic Performance Investigation of A Modern Blended-Wing-Body Aircraft Under the Influence of Heavy Rain Condition, International Congress of the Aeronautical Sciences, 2010.

[8] K. Simhachalam Naidu, G. ShruthiKeerthi, V.V.V Nikhil Bharadwaj, CFD Analysis of Blended Wing Body and B2 Wing, International Journal of Engineering Sciences \& Research Technology, Thomson Reuters Endnote, 2016

[9] Kai Lehmkuehler, KC Wong, and Dries Verstraete, Design and Test of a UAV Blended Wing Body Configuration, International Congress of the Aeronautical Sciences, 2012. 